Sažeci kongresa Hrvatski parodontološki dani 2013.
Zagreb, Hrvatska, 26.-27.4.2013.

\author{
Abstracts of Croatian Periodontology Days 2013 congress \\ Zagreb, Croatia, April 26-27, 2013
}

\author{
Urednik • Editor: Ivan Puhar \\ Predsjednik • President: Darije Plančak
}

\section{ORALNE PREZENTACIJE}

\subsection{PROTETSKE KOMPLIKACIJE DENTALNIH IMPLANTATA \\ Vatroslav Bubalo \\ Klinička bolnica Dubrava}

Protetske komplikacije dentalnih implantata ne nailazimo često opisane u radovima, iako se sami dentalni implantati uspješno koriste već više od 30 godina. Najčešce opisane komplikacije dentalnih implantata jesu komplikacije neposredno nakon kirurškog zahvata, kao što su periimplantitisi ili gubitak kosti. Posvećuje li se sva pozornost uspjehu kirurškog dijela implantacije, te stoga protetski biva zapostavljen? Pacijentica srednjih godina u jesen 2005. godine posjećuje Klinički zavod za stomatološku protetiku, te nakon desetak godina korištenja nekoliko potpunih donjih i gornjih proteza, nezadovoljna njihovim svojstvima odlučuje se na implantaciju dvaju dentalnih implantata. Početkom 2006.godine izrađene su potpune lijevane metalne proteze, $s$ time da je donja bila retinirana s dvije titanske kugle na dva implantata u predjelu donjih očnjaka. U proljeće 2012.godine,pacijentica posjećuje naš Zavod sa željom izrade novih lijevanih metalnih proteza. Pacijentica je primijetila da joj u posljednjih nekoliko mjeseci donja proteza sve slabije retinira, što je objašnjeno trošenjem plastičnih prstenova koji obuhvaćaju titanske kugle. Međutim mjerenjem uočeno je trošenje obiju titanskih kugli. Jedna kugla bila je $0.55 \mathrm{~mm}$, a druga $0.6 \mathrm{~mm}$ uža. Dugogodišnje praćenje pacijenata s dentalnim implantatima, te zajednička suradnja specijalista oralne kirurgije ili parodontologije sa specijalistima stomatološke protetike omogućila bi potpuniju spoznaju o svojstvima dentalnih implantata, kao i komplikacijama poput opisane.

\subsection{KLASIFIKACIJA GINGIVNIH RECESIJA - ŠTO IMA NOVOG? \\ Davor Kuiš, Jelena Prpić, Ivana Šćiran, Andrija Bošnjak \\ Katedra za oralnu medicinu i parodontologiju, Medicinski fakultet u Rijeci, Sveučilište u Rijeci}

Klasifikaciju gingivnih recesija (GR-a) predložio je Miller 1985. godine svrstavši ih u četiri klase temeljem morfologije, etiologije i prognoze uspjeha prekrivanja korijena nakon kirurškog zahvata. Kritike Millerove klasifikacije navode: tešku detekciju keratinizirane gingive, nedovoljnu preciznost u količini gubitka kosti i/ili mekog tkiva u interdentalnom području te nedefiniranu ulogu rotiranog zuba. Upitna je prognosticka vrijednost klasifikacije temeljene na kirurskoj tehnici slobodnog gingivnog transplantata - danas je moguće dobiti potpuno prekrivanje korijena kod GR-a klase III po Milleru. 2011. godine predložena je klasifikacija GR-a temeljena na interdentalnoj razini klinickog pričvrstka (ICAL): tip recesije I (RT I) - nema gubitka ICAL-a; tip (II RT II) - gubitak ICAL-a je manji ili jednak gubitku bukalnog CAL-a te tip III (GT III) - gubitak ICAL-a je veći od gubitka bukalnog CAL-a. RT I povezan je s agresivnim četkanjem u zdravom parodontnom tkivu, dok je kod ostalih tipova recesije prisutna parodontna bolest. RT II povezan je s horizontalnim, a RT III s vertikalnim gubitkom kosti. ICAL predstavlja koronalni limit do kojeg se može prekriti korijen bukalno. Autori ne uzimaju u obzir keratiniziranu gingivu iznad GR-a. Smatraju kako je ta činjenica korisna pri odabiru kirurške tehnike, ali da je njezin utjecaj na uspješnost prekrivanja još sporan. U izlaganju će se, uz predstavljanje obaju klasifikacija, naglasiti njihove prednosti i nedostatci te govoriti o kliničkim smjernicama i prognostickkim faktorima za odabir kirurške tehnike prekrivanja GR-a.

\section{ORAL PRESENTATIONS}

\subsection{PROSTHETIC COMPLICATIONS OF DENTAL IMPLANTS Vatroslav Bubalo \\ Clinical Hospital Dubrava}

Prosthetic complications of dental implants are not often described in papers, althought dental implants are successfully used more than 30 years. Most frequently described complications of dental implants are ones related immediately after surgical procedure, such as periimplantitis or bone loss. Complications related to prosthetic rehabilitation we do not meet often enought. How can we explain insufficiently described complications? Is the focus of our interest only on success of surgical part of implantation, and prosthetic rehabilitation is neglected. Middle aged female patient in the fall of 2005 visited Department of Prosthetic Dentistry, University Hospital Dubrava. After a decade of using several totaly upper and lower dentures, unsatisfied with their characteristic, our patient decided to accept two dental implants in lower jaw, for retention of lower totaly denture. In january 2006, we have made two casted totaly dentures, upper and lower with implant retention. Lower denture was retained with two ball abutments, and position of implants were in cuspid region. In may 2012 same patient visited our clinical department, and desired new casted totaly dentures. Patient noticed that in last several months lower denture with ball abutment was poorly reteined. Blame for loss retention was on Clix inserts ${ }^{\circ}$.Closely look explained what caused problem that patient illustrated. Both ball abutment was worn, one narrower $0.55 \mathrm{~mm}$ and the other $0.6 \mathrm{~mm}$. Patient monitoring is required, especially after a several years of wearing implant supported totaly dentures. Knowledge about prostetic complicatons after a several years of wearing should be often reported.

\subsection{CLASSIFICATION OF GINGIVAL RECESSIONS: AN UPDATE \\ Davor Kuiš, Jelena Prpić, Ivana Šćiran, Andrija Bošnjak \\ Department for Oral Medicine and Periodontology, Medical School, University of Rijeka}

The classification of gingival recessions (GR) was proposed by Miller in 1985. Four types were categorized on the basis on morphological evaluation, etiology and predicting the outcome after surgical procedure. Numerous criticisms of the classification include: difficulty in detection of keratinized tissue, inaccuracy in the amount of bone and/or soft tissue loss in the interdental areas, and inaccurately defined role of tooth malposition. Assessing the value of the Miller classification is questionable since it was based on the free gingival graft. Nowadays, it is possible to achieve complete root coverage even in Class III GR. In 2011, the new classification was proposed based on the level of interproximal clinical attachment level (ICAL): type I (RT I) - no loss of ICAL, RT II - ICAL is less then or equal to the buccal CAL, RT III - ICAL is higher than buccal CAL. RT I was associated with traumatic toothbrushing and healty periodontal tissues; other types were associated with periodontal disease. RT II had horizontal bone loss, and type III infrabony defects. Level of ICAL is the coronal limit of achievable root coverage buccally. In this classification there was no assessment of keratinized tissue. According to the authors, the amount of keratinized tissue is useful in choosing the surgical procedure, but on the outcome is still controversial. Besides presenting both classifications, their advantages and disadvantages will be discussed during the presentation, as well as clinical strategies and factors influencing the choice of surgical procedure. 
3.1. STVARANJE NOVE KOSTI S POMOĆU BCP-KERAMIKE BEZ ILI S RHBMP-2 U KRITIČNOM KOŠTANOM DEFEKTU ŠTAKORA

Ivo Matković1, Daria Skaramuca2, Vedran Katavić3, Vedran Micek4, Igor

Erjavec5, Pamela Habibović6, Huipin Yuan7, Joost D. de Brujin8

IPrivate practice, Zagreb, Croatia

2University of Dubrovnik, Dubrovnik, Croatio

3University of Zagreb, School of Medicine, Department of Anatomy, Zagreb,

Croatia

4Institute for medical research and occupational health, Zagreb, Croatia

5University of Zagreb, School of Medicine, Laboratory for Mineralized Tissue,

Center for Translational and Clinical Research, Zagreb, Croatia

6University of Twente, MIRA - Institute for Biomedical Technology and

Technical Medicine, Department of Tissue Regeneration, Enschede, The

Netherlands

7MIRA Institute, University of Twente, Enschede, The Netherlands, Xpand

Biotechnology BV, Bilthoven, The Netherlands

8MIRA Institute, University of Twente, Enschede, The Netherlands, Xpand

Biotechnology BV, Bilthoven, The Netherlands

Hipoteza je da BCP nosač ( $\beta$-trikalcij fosfat i hidroksiapatit 80:20 omjer) može smanjiti dozu rhBMP-2 za indukciju kosti. Na 120 mužjaka štakora Wistar je postavljen PTFE prsten (negativna kontrola) prazan ili napunjen s BCP (BCP0) s 2.5 (BCP-2.5) ili $5.0 \mu \mathrm{g}$ rhBMP-2 (BCP-5.0). Životinje su žrtvovane 3, $6 \mathrm{i}$ 12 tjedana po implantaciji. Stvaranje nove kosti je kvantitativno utvrđena $\mu \mathrm{CT}$ om (Scanco, Belgium) te izražena kao \% volumena kosti u ukupnom volumenu (\%BV/TV, srednja vrijednost $\pm S D)$. Novostvorena kost je primijećena u svim grupama 3 tjedna po implantaciji - \%BV/TV 24.3 \pm 0.8 u BCP-0, $27.8 \pm 1.2$ u BCP-2.5 27.9 \pm 1.2 , i $24.5 \pm 1.7$ u BCP-5. Šestog tjedna, \%BV/TV je narastao $36.3 \pm 3.7,30.9 \pm 3.7$ i $34.9 \pm 5.0$ u BCP-0, BCP-2.5 i BCP-5. Izmedu 6 i 12 tjedana \%BV/TV se smanjio $-24.7 \pm 3.8,32.5 \pm 1.2$ i $31.3 \pm 2.8$ za BCP-0, BCP-2.5 i BCP-5. \%BV/TV (srednja vrijednost \pm SD ) kao \% površine kosti u ukupnoj površini izračunat je histomofometrijskom analizom potpomognutom računalom (Osteometrics, USA) na dekalciniranim histološkim rezovima. \%BV/TV u

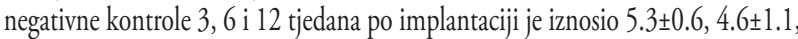
i 6.8 \pm 1.9 . Trećeg tjedna, \% BV/TV bio je $14.7 \pm 0.6$ kod BCP-0, $17.4 \pm 1.3 \mathrm{kod}$ BCP-2.5 i 15.0 1.1 kod BCP-5.0. Šestog tjedna, \% BV/TV je porastao i iznosio $-23.9 \pm 1.6,20.1 \pm 2.6$ i 21.2 \pm 2.9 kod BCP-0, BCP-2.5 i BCP-5.0. Dvanaestog tjedana $\%$ BV/TV je iznosio $15.7 \pm 2.5,20.4 \pm 0.9$, i $20.3 \pm 1.7$ za BCP-0, BCP-2.5, i BCP-5.0, tim slijedom. Statistički značajne razlike među grupama nisu opažene. Ovakvi rezultati sugeriraju da BCP posjeduje intrinzičnu osteoinduktivnu sposobnost koja je samostalno dostatna za popravak koštanih defekata kritične veličine.

\subsection{POVEZANOST PARODONTITISA I ATEROSKLEROTSKIH PROMJENA KAROTIDNIH ARTERIJA}

Ivan Puhar1, Domagoj Vražić1, Ana Badovinac1, Darko Božić1, Darije Plančak1, Arijana Lovrenčić-Huzjan2

IZavod za parodontologiju, Stomatološki fakultet, Sveučilište u Zagrebu

2Klinika za neurologiju, Klinički bolnički centar "Sestre milosrdnice", Zagreb

Parodontitis je utvrđeni čimbenik rizika za razvoj aterosklerotskih lezija. Cilj istraživanja bio je utvrditi povezanost parodontnog statusa i arterijskih morfoloških i funkcionalnih promjena u odnosu na parodontno zdrave osobe. Istraživanjem je pregledano 37 pacijenata s kroničnim parodontitisom, 30 pacijenata s agresivnim parodontitisom (ispitivane skupine) i 61 dobrovoljac sa zdravim parodontom (kontrolna skupina). Parodontni status mjeren je parodontnom sondom i izražen razinom kliničkog pričvrstka. Mjerenja na zajedničkoj karotidnoj arteriji provedena su pomoću uređaja Aloka ProSound ALPHA 10 s $13 \mathrm{MHz}$ linearnom sondom. U odnosu na kontrole, skupina s kroničnim parodontitisom je imala statistički značajno povećane vrijednosti debljine intime-medije $(\mathrm{p}=0,016)$. Navedene promjene nisu uočene u skupini s agresivnim parodontitisom, koja je, međutim, imala signifikantno promijenjene pokazatelje elastičnosti karotidnih arterija u odnosu na kontrolnu skupinu $(\mathrm{p}=0,011)$. Rezultati su pokazali da upalna parodontna bolest može utjecati na arterijska strukturalna i funkcijska svojstva. Potrebna su daljnja istraživanja na većem uzorku pacijenata kako bi se dodatno ustanovio utjecaj parodontitisa na elastična svojstva arterija.
3.2. BONE INDUCTION BY BCP -CERAMICS WITH OR WITHOUT RHBMP-2 IN A RAT CRITICAL-SIZED BONE DEFECTS

Ivo Matković1, Daria Skaramuca2, Vedran Katavić3, Vedran Micek4, Igor

Erjavec5, Pamela Habibović6, Huipin Yuan7, Joost D. de Brujin8

IPrivate practice, Zagreb, Croatia

2University of Dubrovnik, Dubrovnik, Croatia

3University of Zagreb, School of Medicine, Department of Anatomy, Zagreb, Croatia

4Institute for medical research and occupational health, Zagreb, Croatia 5University of Zagreb, School of Medicine, Laboratory for Mineralized Tissue, Center for Translational and Clinical Research, Zagreb, Croatia

6University of Twente, MIRA - Institute for Biomedical Technology and Technical Medicine, Department of Tissue Regeneration, Enschede, The Netherlands

7MIRA Institute, University of Twente, Enschede, The Netherlands, Xpand Biotechnology BV, Bilthoven, The Netherlands

8MIRA Institute, University of Twente, Enschede, The Netherlands, Xpand

Biotechnology BV, Bilthoven, The Netherlands

We hypothesized that BCP-carrier ( $\beta$-tricalcium phosphate and hydroxyapatite in 80:20 ratio) could minimize rhBMP-2 dosage needed for bone induction. 120 male Wistar Han rats received either an empty PTFE ring (sham) or filled with BCP (BCP-0) loaded with 2.5 (BCP-2.5) or $5.0 \mu \mathrm{g}$ rhBMP-2 (BCP-5.0). Animals were sacrificed 3, 6, and 12 weeks post-implantation. 3D bone formation was quantitatively evaluated using $\mu \mathrm{CT}$ (Scanco, Belgium) and expressed as \% bone volume in total volume of intrest (\%BV/TV, mean \pm SD). Newly formed bone was observed in all groups at 3 weeks post-implantation - \%BV/TV 24.3 \pm 0.8 in BCP-0, $27.8 \pm 1.2$ in BCP-2.5 27.9 \pm 1.2 , and 24.5 1.7 in BCP-5. At 6 weeks, \%BV/TV increased slightly $-36.3 \pm 3.7,30.9 \pm 3.7$ and $34.9 \pm 5.0$ in BCP-0, BCP-2.5 and BCP-5, respectively. Between weeks 6 and $12 \%$ BV/TV decreased $-24.7 \pm 3.8,32.5 \pm 1.2$ and $31.3 \pm 2.8$ for BCP-0, BCP-2.5 and BCP-5, respectively. Software-assisted histomorphometry (Osteometrics, USA) was performed on decalcified sections. \% BV/TV, mean $\pm S D$ expressed area percentage of bone in total available space. In the sham groups 3,6 , and 12 weeks post-implantation $\% \mathrm{BV} / \mathrm{TV}$ was $5.3 \pm 0.6,4.6 \pm 1.1$, and $6.8 \pm 1.9$ respectively. At 3 weeks, \% BV/TV was $14.7 \pm 0.6$ in BCP-0, 17.4 \pm 1.3 in BCP-2.5, and 15.0 1.1 in BCP-5.0. At 6 weeks, \% BV/TV slightly increased -23.9 $\pm 1.6,20.1 \pm 2.6$ and $21.2 \pm 2.9$ in BCP-0, BCP-2.5 and BCP-5.0, respectively. At 12 weeks $\% \mathrm{BV} / \mathrm{TV}$ were $15.7 \pm 2.5,20.4 \pm 0.9$, and $20.3 \pm 1.7$ for BCP-0, BCP-2.5, and BCP-5.0, respectively. No statistical differences among groups were observed. These results suggest that $\mathrm{BCP}$ has intrinsic osteoinductivity and can repair critical-sized bone defects alone.

\subsection{CAROTID ATHEROSCLEROSIS IN PATIENTS WITH PERIODONTITIS}

Ivan Puhar1, Domagoj Vražić1, Ana Badovinac1, Darko Božić1, Darije

Plančak1, Arijana Lovrenčić-Huzjan2

1Department of Periodontology, School of Dental Medicine, University of

Zagreb

2 Clinic of Neurology, University hospital center "Sestre milosrdnice", Zagreb

Periodontitis is well established risk factor for the development of atherosclerotic lesions. The aim of this study was to assess the relationship between periodontal status and arterial morphological and functional alterations, compared to the periodontally healthy subjects. The study included 37 patients with chronic periodontitis, 30 patients with aggressive periodontitis (test groups), and 61 volunteers with healthy periodontium (control group). Periodontal condition was assessed in terms of clinical attachment level with a periodontal probe. Measurements on common carotid artery were performed using Aloka ProSound ALPHA 10 with $13 \mathrm{MHz}$ linear probe. In comparison with the control group, chronic periodontitis group showed statistically significant difference in the mean intima-media thickness values $(\mathrm{p}=0,016)$. Aggressive periodontitis group did not show any statistical significance for intima-media thickness values, but had significantly different elastic properties of carotid arteries when compared with the control group $(p=0,011)$. Our results show that inflammatory periodontal disease can affect arterial structural and functional properties. Further investigation with a larger patient sample is required to more accurately assess the arterial stiffness in patients with periodontitis. 
5.1. POSLIEDICE IZOSTANKA SURADNJE KOD PACIJENTA OBOLJELOG OD PARODONTITISA KAO MANIFESTACIJE SUSTAVNE BOLESTI (DIABETES MELLITUS TIP 1)

Domagoj Vražić, Ivan Puhar, Ana Badovinac, Darko Božić, Darije Plančak

Zavod za parodontologiju, Stomatološki fakultet, Sveučilište u Zagrebu

UVOD Pacijent Z.M. u dobi od 50 godina upućen je od strane svog doktora dentalne medicine zbog upale i bolnosti zubnog mesa. Navodi učestalu prisutnost gnoja kod zuba 43, kao i česte upale oko postojećih fiksnoprotetskih radova. PRIKAZ SLUČAJA Prilikom specijalističkog pregleda dijagnosticiran je parodontitis kao manifestacija sustavne bolesti, diabetes mellitusa tip 1. Pacijent u anamnezi navodi alergiju na amoksicilin. Sudjelovanje u Domovinskom ratu i osobna obiteljska tragedija upućuje na povećanu razinu stresa. Redovito posjećuje doktora dentalne medicine i provodi osrednju oralnu higijenu. Prisutan je slatkast zadah i odstojeći rubovi fiksnoprotetskih radova. Tijekom dolazaka razina glukoze u krvi je varirala i u prosjeku iznosila 9,4 mmol/L. Na osnovi izmjerenih parodontoloških parametara provedena je inicijalna terapija i dane su upute u pravilnu oralnu higijenu. Prilikom reevaluacije zamijećeno je značajno poboljšsanje te je predložena promjena fiksnoprotetskih radova i regenerativna terapija na vertikalnim intrakoštanim defektima zubi 43, 47 i 37. Nakon provedenog operativnog zahvata na zubu 43 i stabilne situacije pacijent više ne dolazi na zakazani termin. Nakon godinu i pol dana ponovno se javlja na Zavod za parodontologiju u Zagrebu pri čemu je pregledom ustanovljeno drastično pogoršanje u odnosu na posljednju posjetu. Pacijent dolazi s novim fiksnoprotetskim radovima čiji rubovi na pojedinim mjestima ponovno odstoje i tako otežavaju pravilno provođenje oralne higijene. Kao razlog nedolaska navodi „mirno stanje“ doposljednja dva mjeseca te nemogućnost izostanka s posla. Potrebno je ponoviti inicijalnu terapiju. ZAKLJUČAK Suradnja pacijenta i poštivanje zakazanih termina potporne terapije od iznimne je važnosti za uspješnost terapije parodontoloških bolesti, poglavito kod parodontitisa kao manifestacije sustavnih bolesti.

\section{POSTER IZLAGANJA}

\subsection{ESTETSKO ZBRINJAVANJE GORNJEG SREDIŠNJEG INCIZIVA PO ZAVRŠETKU INICIJALNE TERAPIJE AGRESIVNOG PARODONTITISA Dario Bojčić \\ Ordinacija dentalne medicine "Bojčic"}

UVOD: Pacijent G.P. (32 g.), zdrav, nepušač, upućen je od izabranog stomatologa na Zavod za parodontologiju u studenom 2012. godine zbog estetskog problema uzrokovanog ekstruzijom desnog gornjeg središnjeg sjekutića. Anamnezom, parodontološkim pregledom i analizom ortopantomograma postavljena je dijagnoza agresivnog parodontitisa. PRIKAZ SLUČAJA: Nakon pregleda pacijenta odlučno je da se zbog udaljenog mjesta stanovanja i radnih obveza, terapija obavi u svega tri posjete. U prvoj posjeti su se odstranile supragingivne naslage te izmjerili parodontni džepovi. U drugoj posjeti, nakon tjedan dana, obavljena je inicijalna terapija na desnoj strani gornje i donje čeljusti, te su ekstrahirani zubi 11 i 47. Nakon ekstrakcije rana je zašivena horizontalnim madrac šavom, a zubu je odstranjen korijen $3 \mathrm{~mm}$ od caklinsko-cementnog spojišta. Zub je postavljen u idealan položaj prema susjednim zubima i fiksiran tekućim kompozitom. U trećoj posjeti učinjena je inicijalna parodontološka terapija lijeve strane i šiniranje ekstrahiranog zuba. Pacijent je naručen na recall nakon 6 tjedana, a nakon 3 mjeseca ponovno su izmjereni parodontni džepovi. Planirana je operacija režnja na zubu 17 kako bi se reducirali džepovi. DISKUSIJA: S obzirom da je za implantološku terapiju potrebna barem još jedna operacija, a za izradu fiksnoprotetskog nadomjeska treba brusiti intaktne zube 12 i 21 , postojeće stanje može ostati kao trajno rješenje.

\subsection{STANJE ORALNOG ZDRAVLJA U DOMOVIMA ZA STARIJE I NEMOĆNE SPLITSKO-DALMATINSKE ŽUPANIJE \\ Dario Bojčić1, Ksenija Jorgić-Srdjak2, Srećko Srdjak2, Dubravka Ograjšek Škunca3 \\ 1Ordinacija dentalne medicine "Bojčic" \\ 2Stomatološka poliklinika "Arena", Zagreb \\ 3Privatna ordinacija dentale medicine, Zagreb}

Broj starijih osoba u svjetskoj populaciji rapidno raste posljednjih godina. Udio osoba starijih od 65 godina u Hrvatskoj iznosi 15.62\%, a u Splitsko-dalmatinskoj županiji (SDŽ) 14.28\%. U istraživanju provedenom 2010. i 2011. pregledano je 114 ispitanika, 71 žena i 43 muškarca. Cilj istraživanja bio je utvditi stanje oralnog zdravlja u domovima za starije i nemoćne SDŽ, te predložiti edu-
5.2. THE CONSEQUENCES OF NON-COMPLAINT PATIENT SUFFERING FROM PERIODONTITIS AS A MANIFESTATION OF SYSTEMIC DISEASE (DIABETES MELLITUS TYPE 1)

Domagoj Vražić, Ivan Puhar, Ana Badovinac, Darko Božić, Darije Plančak

Department of Periodontology, School of Dental Medicine, University of

Zagreb

INTRODUCTION Patient Z.M. (50y) was sent by his dentist because of sore and painful gums. He mentions frequent presence of pus around tooth 43 and frequent infections around existing dental bridges. CASE REPORT With careful examination we diagnosed the patient with periodontitis as a manifestation of systemic disease, diabetes mellitus type 1. Patient history states allergy to amoxicillin. Participation in the war and personal family tragedy indicates an increased level of stress. He regularly visits the dentist and performs mediocre oral hygiene. We noticed sweet breath and inappropriate edges of bridges. Level of glucose in his blood varied and averaged $9.4 \mathrm{mmol} / \mathrm{L}$. Periodontal initial therapy was performed, and patient was given instructions on the proper oral hygiene. At reevaluation we observed a significant improvement and advised the patient to change inappropriate prosthetics, as well as regenerative therapy for vertical intrabony defects on teeth 43,47 and 37 . Following the completion of the surgery on the tooth 43 and a stable situation the patient is no longer showing on scheduled appointments. After 18 months patient showed up with new prosthetics that weren't improved much and thus still hampered the proper conduct of oral hygiene. Examination revealed a drastic decline compared to the last visit. The reason of no-shows was "calm situation" until the last two months, and the inability of absence from work. It was necessary to repeat the initial therapy. CONCLUSION Patient compliance and regular appointments make supportive therapy possible and it is of utmost importance for the success of periodontal disease therapy.

\section{POSTER PRESENTATIONS}

\subsection{AESTHETIC RESTORATION OF AN UPPER CENTRAL INCISOR AFTER INITIAL TREATMENT OF AGGRESSIVE PERIODONTITIS Dario Bojčić \\ Dental office "Bojčič"}

Patient G.P. (32), healthy, non-smoker, was referred by his dentist to the Department of Periodontology in a November 2012 due to an aesthetic problem caused by the extrusion of the upper right central incisor. Aggressive periodontitis was diagnosed by anamnesis, periodontal examination and analysis of orthopantomogram. After examining the patient, it was decided that the treatment would be carried out in only three visits. During the first visit, the patent was submitted to a supragingival scaling and measurement of peridontal pockets. During the second visit, a week later, the patient was submitted to initial periodontal treatment of the right upper and lower jaw, and teeth 11 and 47 were extracted. After extraction, the wound was sutured by horizontal mattress suture, and we removed root $3 \mathrm{~mm}$ from the CEJ. The tooth was set in an ideal position to the neighbouring teeth and fixed with flow composite. During the third visit, the patient received initial periodontal treatment of the left side and the extracted tooth was splinted back. The patient was scheduled for a recall appointment after six weeks, and after 3 months we measured periodontal pockets again. We planned a flap surgery on tooth 17 to reduce pockets. Considering that implant treatment requires at least one more surgery, and that fixed prosthodontic treatment requires grinding intact teeth , the existing condition could remain as a long term solution.

\subsection{STATUS OF ORAL HEALTH IN NURSING HOMES RESIDENTS IN SPLIT-DALMATIA COUNTY \\ Dario Bojčić1, Ksenija Jorgić-Srdjak2, Srećko Srdjak2, Dubravka Ograjšek Škunca3 \\ 1Dental office "Bojčić" \\ 2Dental polyclinic "Arena", Zagreb \\ 3Private dental office, Zagreb}

The number of elderly people in the world population has been growing rapidly over the past years. In Croatian population, $15.62 \%$ of the people are older than 65 years, while in the Split-Dalmatia County there are 14.28\%. In the survey conducted in 2010 and 2011, 114 people were examined (71 women and $43 \mathrm{men}$ ). The aim was to gain insight into the status of oral health in nursing home residents in the Split-Dalmatia County. The 
kacijske i preventivne mjere za poboljšnje statusa oralnog zdravlja kod štićenika domova. Kod parodontnog indeksa zajednice najviše je bilo isključenih sekstanata, jedino je u petom sekstantu iskljucenih bilo manje od $50 \%$. Nakon isključnih sekstanata slijede oni u kojima je prisutan vidljiv supragingivni ili subgingivni kamenac. I kod analize gubitka pričvrstka najviše je zabilježeno isključenih sekstanata, a zatim po učestalosti slijedi gubitak pričvrstka od 4-5 mm. Potpuno bezubih ispitanika je bilo $52.6 \%$, njih $42.1 \%$ je nosilo potpunu protezu u gornjoj čeljusti a 33.6\% u donjoj čeljusti. Protetsku terapiju u gornjoj čeljusti ne treba $37.7 \%$ ispitanika, a u donjoj $33.3 \%$. Izradu potpune proteze u gornjoj čeljusti treba 36\% ispitanika, dok ih u donjoj čeljusti treba 32.5\%. KEP indeks je prosječno iznosio 26. Preventivnim stomatološkim mjerama koje bi se provodile već od najranije dobi, može se smanjiti pojavnost karijesa i parodontnih bolesti koji su vodeći uzrok gubitka zubi u populaciji.

\subsection{OPSKRBA INTRAKOŠTANIH DEFEKATA KOŠTANIM NADOMJESNIM MATERIJALOM I MEMBRANOM \\ Ivana Bradvica, Tomislav Domić, Mladen Klemenčić \\ Stomatološka poliklinika Zagreb}

Cilj regenerativne kirurgije je ostvariti ponovno stvaranje cementa, periodontalnog ligamenta i nove kosti. Jedna od terapijskih metoda je regeneracija upotrebom koštanih nadomjesnih materijala i membrana. Pacijent M.B. (41 g), dobrog općeg zdravstvenog stanja. Dg. Agresivni generalizirani parodontitis. Nakon ekstrakcije zuba 34 i 35 provedena je inicijalna parodontološka i sistemska antibiotska terapija amoksicilinom i metronidazolom. Tri mjeseca po završetku inicijalne terapije učinjena je reevaluacija. Zubi 31 i 41 su avitalni, povećano pokretljivi, dubine sondiranja su mezijalno 11, distalno i lingvalno 4, te vestibularno $5 \mathrm{~mm}$. Stoga je provedeno endodontsko liječenje i imobilizacija istih. Tri mjeseca nakon provedenog endodontskog liječenja pristupa se regenerativnoj kirurškoj terapiji preostalog intrakoštanog defekta, te stavljanju koštanog substituta (Bio-oss, Geistlich) i resorptivne membrane (Bio-Gide, Geistlich). Postoperativni tijek je uredan, kontrolni pregledi su u početku 1x tjedno, a potom 1 x mjesečno tijekom 6 mjeseci. Nakon dvije godine kontrolni rtg je pokazao smanjenje koštane destrukcije, a dubine sondiranja su smanjene na 4 $\mathrm{mm}$. Dakle, nakon adekvatne endodontske i parodontološke terapije, s provedbom regenerativnog kirurškog zahvata, zubi su zadržali svoju funkciju uz vidljiv oporavak koštanog defekta.

\subsection{AUTOLOGNI ANTAGONIST RECEPTORA INTERLEUKINA 1 (ORTHOKIN@) I ORTODONTSKI POMAK U TERAPIJI AGRESIVNOG PARODONTITISA \\ Kristina Đurkan1, Ivan Puhar2, Darije Plančak2, Marin Piskač3 \\ IPoliklinika Šlaj-Anić, Zagreb \\ ZZavod za parodontologiju, Stomatološki fakultet, Sveučilište u Zagrebu 30rdinacija dentalne medicine, Maruševac}

Cilj je bio prikazati mogućnost primjene Orthokina nakon provedene inicijalne terapije pacijenta s agresivnim parodontitisom (AgP). Orthokin je autologno kondicionirani serum dobiven iz venske krvi pacijenta. Visoka koncentracija IL-1Ra blokira IL-1 receptor i njegovo štetno djelovanje, uspostavljajući ravnotežu imunološkog odgovora na mjestu primjene. Pacijentici M.F. (28.g) pregledom je dijagnosticiran AgP. Glavni razlog dolaska bila je migracija i pomičnost zuba 21 te krvarenje. Uz inicijalnu terapiju predložena je terapija Orthokinom, uzet uzorak sline i venske krvi. Prije i nakon supragingivnog čišcenja, izmjereni su džepovi, indeksi plaka, krvarenja i pomičnosti. Dobiven autologno kondicionirani serum apliciran je na mjestima najdubljih džepova pet puta u razmacima od dva dana. Mjesta aplikacije zaštićena su parodontnim zavojem. Pacijentica je upućena u provođenje oralne higijene te su uslijedile mjesečne kontrole. U sklopu terapije ortodontskim gumicama korigiran je položaj zuba 21 i fiksiran kompozitnom šinom. Šest mjeseci nakon provedene parodontološke terapije potpomognute aplikacijom Orthokina i manjom ortodontskom korekcijom znatno se poboljšalo parodontno stanje. Na zubu 21 eliminirani su džepovi i smanjena je palatinalna retrakcija gingive s $3 \mathrm{na} 0,5 \mathrm{~mm}$. Na ostalim zubima nema rezidualnih džepova, gingiva ima zdravi izgled bez krvarenja. U terapiji nisu korišteni antibiotici. Pokazano je kako lokalna primjena Orthokina uz manju ortodontsku korekciju može doprinijeti boljem cijeljenju i ishodu inicijalne parodontološke terapije i tako poslužiti kao moguća alternativa kirurškim zahvatima kod agresivnog parodontitisa.
CPITN Index has shown the greatest number of excluded sextants, while only the fifth sextant had less than $50 \%$ of excluded teeth. Excluded sextants were followed by those in which supragingival or subgingival calculus was present. In the analysis of attachment loss, the excluded sextants were the ones most commonly recorded, followed by the loss of attachment of $4-5 \mathrm{~mm}$. There were $52.6 \%$ fully edentulous persons, of which $42.1 \%$ had a complete denture in the upper jaw and $33.6 \%$ in the lower jaw. Prosthetic treatment in the upper jaw was required in $37.7 \%$ of the surveyed and in the lower jaw in $33.3 \%$. Complete denture in the upper jaw was required by $36 \%$ of the surveyed and in the lower jaw by $32.5 \%$. The DMFT (decay,missed, filled teeth) index was approximately 26. Preventive dental measures applied from an early age would result in reduced occurrence of caries and periodontal disease which are the leading cause of tooth loss in the population.

\subsection{TREATMENT OF INFRABONY DEFECTS WITH BONE SUBSTITUTE MATERIALS AND MEMBRANE}

Ivana Bradvica, Tomislav Domić, Mladen Klemenčić

Dental Polyclinic Zagreb

The aim of regenerative surgical procedures is to achieve a new formation of cementum, periodontal ligament and bone. One of the therapy methods is regeneration using bone substitute materials and membrane. Patient M.B. (41) was systemically healthy. The patient had been diagnosed with generalized aggressive periodontitis. Post tooth extraction an initial therapy had been completed and systemic antibiotics (amoxicilin and metronidazole) were administered. Three months after completing the initial therapy, a re-evaluation was performed. Teeth 31 and 41 were non-vital with increased tooth mobility. Probing depth on mesial surface was 11, distal and lingual 4 and bucal $5 \mathrm{~mm}$. For this reason an endodontic treatment and immobilization of these teeth were performed. Regenerative surgical treatment included using bone substitute material ( BioOss, Geistlich) and membrane (Bio-Gide, Geistlich). This tretment was undertaken after 3 months. Recall appointments were at the beginning every week , thereafter once a month for the following next six months. Two years later the control radiograph showed a decrease in bone destruction and probing depths were reduced to $4 \mathrm{~mm}$. After appropriate endodontic, periodontal and surgical treatments there has been a notable recovery of the periodontium.

\subsection{AUTOLOGOUS INTERLEUKIN-1 RECEPTOR ANTAGONIST (ORTHOKIN@) AND MINOR ORTHODONTIC TREATMENT IN THERAPY OF AGGRESSIVE PERIODONTITIS \\ Kristina Đurkan1, Ivan Puhar2, Darije Plančak2, Marin Piskač3 \\ IPolyclinic Šlaj- Anić, Zagreb \\ 2Department of Periodontology, School of Dental Medicine, University of \\ Zagreb \\ 3Dental practice, Maruševac}

The aim of this case was to show the possibility of Orthokin application after initial periodontal therapy in patients with aggressive periodontitis. Orthokin ${ }^{8}$ is autologous conditioned serum obtained from venous blood. High concentrations of IL-1Ra block IL 1 receptor and its harmful effects, establishing a balance of the immune response at the site of application. Patient M.F. (age 28, nonsmoker, healthy) was diagnosed with aggressive periodontitis. Main complaint was migration and mobility of tooth 21 and gingival bleeding. During initial treatment the patient was offered Orthokin application. The pockets, plaque index (API), gingival bleeding ( $\mathrm{PBI}$ ) and tooth mobility were measured before and after supragingival cleaning. Orthokin ${ }^{\circ}$ was applied in deepest pockets five times every second day. Injection sites were protected with periodontal dressing. The patient was instructed in oral hygiene and subsequent monthly controls. After the first month saliva sample was taken, and after 3 months indices were measured again. Using elastic bands frontal teeth were realigned and fixed with composite splint. Reevaluation after six months showed significant improvement. There were no active residual pockets after debridement. Palatal gingival retraction on tooth 21 reduced from $3 \mathrm{~mm}$ to $0.5 \mathrm{~mm}$. Gingiva had a healthy appearance without bleeding. Therapy didn't include systemic antibiotics. A case report demonstrated that local application of Orthokin ${ }^{\circ}$ with minor orthodontic correction can contribute to a better outcome of initial periodontal therapy, and thus serve as an alternative to surgical treatment of aggressive periodontitis. 
5.1. AUGMENTACIJA ALVEOLARNOG GREBENA NAKON NEUSPJELE ORTODONTSKE TERAPIJE RETINIRANOG OČNJAKA - PRIKAZ SLUČAJA

Zrinka Ivanišević1, Marko Matijević2, Zvonimir Užarević3

1Ordinacija dentalne medicine Zrinka Ivanišević dr.med. dent.,Osijek

2Medicinski fakultet, Sveučilište Josipa Jurja Strossmayera, Osijek

3Učiteljskifakultet, Sveučilište Josipa Jurja Strossmayera, Osijek

Nepovoljan položaj retiniranog očnjaka u gornjoj čeljusti može imati za posljedicu nemogućnost adekvatne ortodontske terapije. Kirurško odstranjivanje oćnjaka može dovesti do masivnog gubitka alveolarne kosti te svakako kompromitirati daljnju kirurško-protetsku rehabilitaciju. Cilj je što brža i efikasnija terapija, odnosno rješavanje problema u što manje kirurških zahvata, što ponekad može biti kontraproduktivno i kompromitirajuće za konačan rezultat liječenja. Plan terapije uvijek mora biti jasan i svakako treba voditi računa o izboru i redoslijedu tehnika koji su osnovna pretpostavka uspješne terapije. U našem slučaju zbog velikog koštanog defekta nakon uklanjanja očnjaka te zbog nemogućnosti imedijatne ugradnje implantata, korištena je klasična tehnika vođene koštane regeneracije (GBR) prije same implantacije. $U$ tu svrhu koristili smo kombiniranu tehniku regeneracije kosti upotrebom autogenog transplantata i ksenotransplantata Bio-Oss te prirodne resorbirajuce membrane Bio-Gide.

\subsection{PROŠIRENJE POJASA PRIČVRSNE GINGIVE BEZUBOG GREBENA PRIJE PROTETSKE TERAPIJE IMPLANTATIMA PRIKAZ SLUČAJA \\ Jerko Jakšićl, Darije Plančak2 \\ IPrivatna stomatološka ordinacija Ana Jakšić \\ ZZavod za parodontologiju, Stomatološki fakultet, Sveučilište u Zagrebu}

Širina pričvrsne gingive oko dentalnih implantata može varirati od nule do nekoliko milimetara i može poboljšati estetiku i olakšati kontrolu plaka. Znanstveno nije u potpunosti dokazano da širina pričvrsne gingive povećava postotak uspješnosti i preživljavanja implantata. Ipak kliničari su mišljena da adekvatna širina pričvrsne gingive olakšava izradu protetske suprastrukture i kontrolu plaka. Zbog razlike periimplantatnog tkiva u odnosu na parodontni kompleks oko zuba periimplantatna mukoza je podložnija upali i u prisutnosti plaka pomanjkanje ovih čimbenika može dovesti do lakšeg razvijanja marginalne upale mukoze i resorpcije kosti. Kirurške zahvati koji se koriste kod povećanja pojasa pričvrsne gingive su apikalno pomaknuti režanj, slobodni gingivani i vezivni transplantat, razni peteljkasti i lateralno pomaknuti režnjevi, a također i vestibuloplastika s produbljenjem vestibuluma. Prikazana su dva klinička slučaja augmentacije pomoču nepčanog slobodnog gingivalnog transplantata. Slučajevi se razlikuju po vremenu augmentiranja,odnosno otvaranja implantata i postavljanja nadogradnji za cjeljenje. Prvi slučaj je augmentiran prije otvaranja implantata. Potom se prilikom postavljanja nadogradnje za cijeljenje režanj pomaknuo apikalno. U drugom slučaju augmentacija je učinjena kod već postavljenih nadogradnji za cijeljenje. Periimplantatni problemi se u većini slučajeva nalaze u fazi održavanja gdje je čest nalaz neadekvatna širina pričvrsne gingive, gingivna hiperplazija i mukozitis. Uspostava cirkumferentog zatvaranja gustim vezivnim tkivom može smanjiti navedene simptome i olakšati buduću parodontnu terapiju.

\subsection{PRIPREMA PACIJENTA ZA ORTODONCIJU KOREKTIVNIM MUKOGINGIVALNIM ZAHVATIMA}

Ivana Jurčic Čulina1, Domagoj Vražić2, Marija Ivić-Kardum2

IPrivatna ordinacija, Zagreb

ZZavod za parodontologiju, Stomatološki fakultet, Sveučilište u Zagrebu

UVOD Pacijentica LJ.P. u dobi od 45 godina upućena je na Zavod za parodontologiju u Zagrebu od strane svog stomatologa radi povlačenja zubnog mesa na više zuba. PRIKAZ SLUČAJA Iz anamneze smo utvrdili da pacijentica nije pušač, te da je generalno zdrava. Pacijentica je koristila tvrdu četkicu za održavanje oralne higijene, kao i nepravilnu tehniku četkanja. Nakon datih pravilnih uputa o higijeni (tehnika četkanja po modificiranom Stillmanu), pacijentici je napravljen parodontološki status, kojim je ustanovljeno da nema znakova parodontitisa. Mjerenjem je utvrđena gingivna recesija u području zuba 13 od $3 \mathrm{~mm}$, zuba 23 u iznosu $6 \mathrm{~mm}$, te zuba 33 od $5 \mathrm{~mm}$. Pacijentici je napravljeno površinsko čiśćenje zubi u nekoliko posjeta. Za to vrijeme je praćeno je li je pacijentica promijenila metodu četkanja, te da li su se možda pojedine resecije zaustavile. Pacijentici je preporučena i napravljena korekcija recesija mukogingivalnim zahvatima na zubu 13 (koronarno pomaknut režanj), na zubu 23 (koronarno pomaknuti režanj s Mucodermom) i na zubu 33 (koronarno pomaknuti režanj sa slobodnim vezivnim transplantatom). DISKUSIJA Pokretljivost zuba je primje-
5.2. AUGMENTATION OF ALVEOLAR RIDGE AFTER FAILED ORTHODONTIC THERAPY OF A RETAINED CANINE TOOTH - CASE REPORT

Zrinka Ivanišević1, Marko Matijević2, Zvonimir Užarević3

1Private dental Practice Zrinka Ivanišević DMD, Osijek

2 Faculty of Medicine, University Josip Juraj Strossmayer, Osijek

3Faculty of Education, University Josip Juraj Strossmayer, Osijek

Unfavorable position of a retained canine tooth in the upper jaw can lead to inability of appropriate orthodontic therapy. Surgical removal of a canine tooth can lead to a massive loss of alveolar bone and compromise further surgical-prosthetic rehabilitation. The goal is the fastest and the most efficient therapy that is unravelling the problem with less surgical intervention which can sometimes be contraproductive and can compromise the final result of the treatment. Therapy plan always has to be clear and take account of the selection and sequence of techniques that are basicprecondition of a successful therapy. Due to the large bone defect after the removal of the canine tooth and the impossibility of an immediate placement of the implant, in our case, we used the classic technique of guided bone regeneration (GBR) before the implantation. For that purpose we used combined technique of bone regeneration by using an autogenous graft and xenograft Bio-Oss and bioresorbable membrane Bio-Gide".

\subsection{INCREASING THE WIDTH OF KERATINIZED TISSUE IN EDENTULOUS JAW AREA BEFORE RESTORATIVE PHASE ON IMPLANTS \\ Jerko Jakšić1, Darije Plančak2 \\ 1Private dental office Ana Jakšić \\ 2Department of Periodontology, School of Dental Medicine, University of Zagreb}

The width of keratinized soft tissue around dental implants may vary between zero and several millimeters, and may improve plaque control and enhance esthetics. Although scientific evidence in most part is missing and there are no evidence that width of attached gingiva can take a role on survival or success of dental implants, most of the clinicians believe that adequate width of keratinized tissue facilitate restorative faze and plaque control. Because of the difference between peri-implant mucosa and gingival tissue and lack of the proper protective factors, peri-implant mucosa in the presence of plaque accumulation can develop inflammation and bone loss around implants. Surgical technique to obtain adequate amount of keratinized tissue are vestibuloplasty, apically positioned flap, free gingival graft, connective tissue graft, rotated and laterally positioned flaps. Two cases of augmenting of edentulous posterior mandible are presented with palatal free gingival grafts with difference in time of transplantation. First case is augmented before opening implants for receiving gingival former. And second one is augmented while gingival formers were placed for some time. Peri-implant problems in most cases are observed in the maintenance and recall phase and where we find inadequate zone with of keratinized tissue ,mobility of the soft tissue, gingival hyperplasia and mucositis . Establishment of a circumferential sealing effect by a dense connective tissue collar at the site of implant penetration into the contaminated environment of the oral cavity is needed for a longterm implant success.

\subsection{PRE-ORTHODONTIC TREATMENT WITH CORRECTIVE MUCOGINGIVAL SURGERY PROCEDURES \\ Ivana Jurčić Čulina1, Domagoj Vražić2, Marija Ivić-Kardum2 \\ 1Private dental practice, Zagreb \\ 2Department of Periodontology, School of Dental Medicine, University of Zagreb}

INTRODUCTION Patient LJ.P., 45 years of age, was referred by her dentist to the Department of Periodontology in Zagreb due to gingivalrecession on several teeth. CASE REPORT On the basis of dental history, it was established that the patient is a non-smoker, and in a good general health. The patient used a hard tooth brush for oral hygiene, and brushed her teeth inappropriately. After having instructed the patient how to clean her teeth properly (modified Stillman brushing technique), we measured her periodontal status, which had showed no signs of periodontitis. Measurements have shown gingival recession in the area of tooth 13 of $3 \mathrm{~mm}$, tooth 23 of $6 \mathrm{~mm}$, and tooth 33 of $5 \mathrm{~mm}$. On several visits the patient's teeth were professionaly cleaned and checked whether she had changed the method of brushing and whether individual recessions had stopped. The patient was advised and agreed to have a recession corrected through mucogingival treatment on teeth 13 (coronally repositioned flap), 23 (coronally repositioned flap with Mucoderm) and 33 (coronally repositioned flap with a free connective tissue graft). DISCUSSION Tooth mobility was observed on tooth 31 , probably due to reversed over- 
ćena na zubu 31, vjerojatno zbog obrnutog preklopa u području zuba 21/31. Budući da je pacijentici sugerirana ortodontska terapija radi prethodno navedenog obrnutog preklopa, korektivna mukogingivalna terapija bila je svakako potrebna. Odabir kirurškog zahvata ovisi o veličini recesije, spremnosti pacijenta na financijski izdatak te spremnosti na trajanje pojedinih zahvata. ZAKLJUČAK Korektivnim kirurškim parodontološkim zahvatima možemo uspješno liječiti i sanirati recesije gingive.

\subsection{UPOTREBA DERIVATA CAKLINSKOG MATRIKSA U KOMBINACIJI SA ALOPLASTIČNIM KOŠTANIM NADOMJESTKOM U LIJEČENJU PARODONTITISA: PRIKAZ SLUČAJA \\ Maja Kostelić Stunić1, Darije Plančak2 \\ IStomatološka poliklinika Zagreb \\ ZZavod za parodontologiju, Stomatološki fakultet, Sveučilište u Zagrebu}

SVRHA RADA Jedan od glavnih ciljeva parodontnog liječenja je kontrola upale. Međutim, kao posljedica prijašnje aktivnosti bolesti često nastupaju anatomske promjene koje se moraju ukloniti. Regeneracija parodonta, ili potpuna obnova građe i funkcije izgubljenog parodontnog tkiva, cilj je kojem se teži. Proteini caklinskog matriksa ekstrahirani iz cakline zametaka svinja, stvaraju korijensku površinu pogodnu za migraciju i selektivno pričvršćivanje stanica parodonta. Sukladno stvaranju novog pričvrstka, alveolarna kost se također može regenerirati zahvaljujući osteogenoj aktivnosti obnovljenog periodontalnog ligamenta. MATERIJALI I METODE Pacijentu u dobi od 42 godine dijagnosticiran je generalizirani agresivni parodontitis. Nakon završenog konzervativnog liječenja uz dodatnu primjenu sistemskih antibiotika, pristupilo se kirurškom zahvatu u području mandibularnog desnog očnjaka (dvozidni intrakoštani džep). Bukalno je odignut mukoperiostalni režanj. Uklonjeno je granulacijsko tkivo vezano uz kost, a površine korijena su temeljito očišcene. Zatim su u području intrakoštanog džepa primjenjeni proteini caklinskog matriksa (Emdogain) u kombinaciji $\mathrm{s}$ aloplastičnim koštanim nadomjestkom (Bone ceramic). Režanj je pažljivo reponiran i osiguran modificiranim vertikalnim madračnim šavom i pojedinačnim 4.0 šavovima (prolen). REZULTATI Reevaluacija stanja parodonta učinjena je nakon 1, 3, i 6 mjeseci. Vidljiva je optimalna kontrola plaka i odlično cijeljenje mekog tkiva. Klinička i radiografska procjena razina pričvrstka učinjena je 6 mjeseci nakon operativnog zahvata. ZAKLJUČAKProteini caklinskog matriksa pružaju obećavajući pristup regeneraciji izgubljenog parodontnog tkiva.

\subsection{OPSKRBA TRAUME I KOMPLICIRANE FRAKTURE GORNJEG}

SJEKUTIĆA - PRIKAZ SLUČAJA

Hana Kralj1, Domagoj Vražić2, Kristijan Rudić3, Andrej Aurer2

1Dentalna poliklinika $K 2$

ZZavod za parodontologiju, Stomatološki fakultet, Sveučilište u Zagrebu

3Dentalni laboratorij Rudic

Nakon pada s bicikla pacijentica (18) dolazi zbog pomičnog gornjeg desnog sjekutića. Pregledom je ustanovljena horizontalna fraktura u cervikalnoj trećini zuba. Hitno je napravljena vitalna ekstirpacija pulpe i endodontsko liječenje. Zub je potom pripremljen za izradu nadogradnje. $U$ istoj posjeti izrađen je jednodijelni provizorni nadomjestak kombinacijom kompozitnog kolcića, kompozita i akrilatnog zuba iz garniture za proteze. Nadomjestak je privremeno cementiran. Uslijedio je operativni zahvat produljenja kliničke krune. Rubovi frakturiranog korijena su prikazani, a režanj apikalno pomaknut. Nakon 2 mjeseca cijeljenja, postavljena je nadogradnje od kompozitnog kolčića i nova provizorna krunica. U cijelom periodu rješavanja ovog slučaja izrađena su čak 3 privremena nadomjestka pomoću kojih se formiralo meko tkivo tijekom cijeljenja. Prije izrade definitivne krunice, meko tkivo je u potpunosti formirano a cijeljenje završeno. Konačna krunica izrađena je od HT cirkonijevog dioksida. Terapija je trajala tri mjeseca.

\subsection{KADA SE ODLUČITI ZA OČUVANJE ZUBA U FRONTI KOD UZNAPREDOVALOG PARODONTITISA \\ Dunja Kuliš, Ljiljana Pater-Henigsman, Sanja Gruden-Pokupec \\ Stomatološka poliklinika Zagreb}

UVOD Kronični parodontitis je upalna promjena gingive i progresivni gubitak parodontnog ligamenta i alveolarne kosti. Prije protetske terapije prioritet je parodontna terapija, koja nije jednostavna i nerijetko je rezultat nepredvidiv. CILJ Cilj je operativnim zahvatom sačuvati postojeće zube. Glavni cilj je regeneracija kosti uz što manju postoperativnu gingivnu recesiju. METODE U oba slučaja rađena je operacija režnja s postavljanjem bioresorptivne membrane, a u defekt granulat. PRIKAZ SLUČAJA I Pacijentica se javlja zbog upale i povećane po- lapping in the area of teeth $21 / 31$. Since the patient was advised to have an orthodontic therapy due to the mentioned reversed over-lapping, a corrective mucogingival therapy was necessary in this case. CONCLUSION It is possible to successfully treat and stop gingival recessions by means of corrective periodontal surgical interventions and good patient compliance.

\subsection{THE USE OF ENAMEL MATRIX DERIVATIVE IN COMBINATION WITH SYNTHETIC BONE GRAFT IN THE TREATMENT OF PERIODONTITIS: A CASE REPORT \\ Maja Kostelić Stunić1, Darije Plančak2 \\ IDental Polyclinic Zagreb \\ ZZavod za parodontologiju, Stomatološki fakultet, Sveučilište u Zagrebu}

AIM One of the initial objectives of periodontal therapy is infection management. However, anatomic changes resulting from past disease activity often occur and must be eliminated. Periodontal regeneration, or the complete restoration of the structure and function of lost periodontal tissues, is the ideal goal. Enamel matrix proteins extracted from developing porcine embryonic enamel, create a suitable root surface for selective periodontal cell migration and attachment. Subsequent to formation of new attachment, alveolar bone can also be regenerated due to the osteogenic capacity of restored periodontal ligament. MATERIAL AND METHODS A 42- year old male was diagnosed with generalized aggressive periodontitis. Following completion of non-surgical treatment with adjunctive systemic antibiotics, surgical treatment was performed for a mandibular right canin (2-wall intrabony defect). Mucoperiosteal flap was elevated buccally, granulation tissue adherent to the bone was removed, and root surfaces were meticulously cleaned. Subsequently, a mixed regenerative material containing enamel matrix proteins and alloplastic bone substitute was placed in the intrabony defect. Flap was carefully adapted and secured with modified vertical mattress suture and simple interrupted 4.0 prolene sutures. RESULTS The patient was reviewed at 1, 3 and 6 months. Optimal plaque control was evident, and soft tissue healing was excellent. Clinical and radiographic assessment of the attachment levels will be performed 6 months following surgical treatment. CONCLUSION Enamel matrix derivatives may provide a promising approach for the regeneration of lost periodontal tissues.

\subsection{TREATMENT OF AN UPPER INCISOR TRAUMATIC FRACTURE - A CASE REPORT}

Hana Kralj1,Domagoj Vražić2, Kristijan Rudić3, Andrej Aurer2

1Dental polyclinic K2

2Department of Periodontology, School of Dental Medicine, University of

Zagreb

3Dental laboratory Rudić

An 18-year-old female patient presented herself at our practice after a biking accident. Due to pain and tooth mobility of the upper right incisor, she was in need of treatment. Clinical examination revealed a horizontal, slightly oblique crown and root fracture in the cervical third of the root. Pulp extirpation and an endodontic treatment were performed in the same visit. The root canal was prepared for a post. A provisional crown was placed, for which a combination of composite post and acrylic denture tooth was used. The next step was the surgical crown lengthening procedure and the margins of the fractured root were positioned supragingivally. After a two month healing period a new composite post was seated together with a new temporary crown. During the treatment three temporary crowns were serially changed to enhance and lead soft tissue to obtain desired position and form. The permanent crown was made out of HT zirconium dioxide. The entire procedure lasted for three months.

\subsection{WHEN TO DECIDE TO PRESERVE FRONT TEETH WIH ADVANCED PERIODONTITIS \\ Dunja Kuliš, Ljiljana Pater-Henigsman, Sanja Gruden-Pokupec \\ Dental Polyclinic Zagreb}

INTRODUCTION Chronic periodontitis includes the inflammatory changes of gingiva and the progressive loss of periodontal ligament and alveolar bone. Prior to prosthodontic therapy, the priority is the complex periodontla therapy and the outcome is often very unpredictable. AIM The aim is to preserve the existing teeth by surgical intervention. The main goal is the bone regeneration followed by minimal postoperative gingival recession. METHODS Flap surgery was performed by placing bioresorptive membrane and by allocating granules into the defect. CASE REVIEW I The patient contacted us due to in- 
kretljivosti zuba 22 (2-3). Zub je endodontski liječen s nadogradnjom i krunicom. Na radiološkoj slici se uočava veliki gubitak kosti, što ugrožava vitalni zub 21. PRIKAZ SLUCCAJA II Pacijentica se javlja zbog edema i bolova u području inciziva gornje čeljusti. Na radiološkoj slici uočen je proces na 11, te velika resorpcija kosti u području 11,12 i 21. Plan terapije: Nakon inicijalne terapije i stabilizacije fiksnih protetskih radova učinjena je operacija režnja s ugradnjom Bio-Oss spongiose i Bio-gide membrane. REZULTATI SLUČAJEVA I i II : 1. nema upale 2. smanjena pokretliivosti zubi 3. stvara se nova koštana struktura 4. minimalna retrakcija gingive. ZAKLJUČAK Kod uznapredovalog parodontitisa s velikim gubitkom kosti mogu se postići dobri rezultati ako je učinjena inicijalna terapija i operativni zahvat. Dobiveni su bolji klinički i radiološki parametri tih zubi i mogućnost izrade novih protetskih struktura. Očekivana retrakcija gingive je minimalna.

\subsection{FRAKTURA DENTALNOG IMPLANTATA USLJED NEPOVOLJNOG} OKLUZALNOG OPTEREĆENJA

Marija Nosić1, Tajana Novak2, Marija Ivić-Kardum3, Andrija Bošnjak1

IZavod za oralnu medicinu i parodontologiju, Studij dentalne medicine,

Sveučilište u Splitu

2Privatna ordinacija, Zagreb

3Zavod za parodontologiju, Stomatološki fakultet, Sveučilište u Zagrebu

Ugradnja implantata danas je sve češći izbor terapije zbog brojnih prednosti i velikog raspona mogućnosti ćime ovaj vid terapije prednjači pred drugim zahvatima u dentalnoj medicini. Budući da je doveo do uzleta u dentalnoj medicini i sve učestalije primjene, broj ugrađenih implantata iz dana u dan se povećava, a s njme raste i učestalost komplikacija. Fraktura dentalnog implantata spada u rijetke i kasne implantoprotetske komplikacije i obično predstavlja znak pretjeranog okluzalnog opterećenja. Ovdje prikazujemo slučaj 67-godišnje pacijentice koja se javila zbog pomičnosti implantoprotetski nadomještenog zuba u regiji 45. Radiološkom analizom utvrđeno je da je razlog pomičnosti fraktura vrata implantata. Radilo se o 3I implantatu promjera $3.3 \mathrm{~mm}$ na kojem je izrađena metalnokeramička krunica. Anamnestički je utvrdeno da pacijentica nema temporomandibularne i okluzalne poremećaje. Oralna rehabilitacija provedena je prije šest godina i to nadomještanjem izgubljenih zuba ugradnjom implantata u području zuba 36,37 i 45. Fraktura implantata predstavlja ireverzibilnu implantoprotetsku komplikaciju te je u ovom slučaj odlučeno eksplantirati frakturirani implantat $\mathrm{i}$ augmentirati eksplantacijski defekt te ponovno ugraditi implantat šireg promjera na isto mjesto nakon cijeljenja.

\subsection{PREKRIVANJE KORIJENA U PODRUČJU DONJIH PREDNJIH ZUBA - PRIKAZ DVAJU KIRURŠKIH TEHNIKA \\ Jelena Prpić1, Davor Kuišl, Ivana Šćiran1, Marija Ivić-Kardum2, Andrija Bošnjak1 \\ IKatedra za oralnu medicinu i parodontologiju, Medicinski fakultet u Rijeci, Sveučilište u Rijeci \\ 2Zavod za parodontologiju, Stomatološki fakultet, Sveučilište u Zagrebu}

Gingivalne recesije na bukalnim površinama naročito prednjih zuba uobičajene su u populacijama s visokim standardom oralne higijene. Uzročnim čimbenicima smatraju se traumatsko četkanje, morfologija alveolarnog grebena i gingive, te eventualno funkcijski poremećaji. Kirurške tehnike za prekrivanje recesija mogu se podijeliti u peteljskaste režnjeve i slobodne transplatate mekih tkiva. U kombinaciji s navedenim mogu se rabiti i regenerativni materijali. Danas se zlatnim standardom za prekrivanje recesija smatra zahvat koronalno pomaknutog režnja sa slobodnim vezivnim transplatatom $(K P R+S V T)$. Potencijal prekrivanja recesija slobodnim gingivalnim transplantatom (SGT) je značajno lošiji. Međutim, većina prikaza slučajeva i istraživanja odnosi se na zube gornje čeljusti. U području donjih prednjih zuba uspjeh je često kompromitiran uskom zonom pričvrsne gingive, visokim pripojem frenuluma i plitkim vestibulumom. Stoga je nedavno predložena tehnika parcijalno epiteliziranog slobodnog gingivalnog transplantata (PE-SGT) kojom se može predvidljivo poboljšati estetski ishod prekrivanja recesija u navedenom području, a kojom se "zaobilazi" nepovoljan utjecaj gore navedenih čimbenika. Dodatna prednost ove tehnike je i zadržavanje originalnog smještaja mukogingivalne linije, što nije slučaj s "klasičnim" SGT-om. Prikazana su dva slučaja gingivalnih recesija u području donjih prednjih zuba, te njihovo prekrivanje dvijema tehnikama: KPR+SVT i PE-SGT. flammation and increased tooth mobility 22 (2-3). The tooth was endodontically treated by post and crown. In the radiological pictures we noticed the significant bone loss, that compromised vital tooth 21. CASE REVIEW II The patient contacted us due to edema and the pain in the maxilla incisor area. In the radiological picture we noticed the process in 11 and the significant bone resorption in the area 11,12 and 21. Therapy plan: After initial therapy and fixed prosthodontic appliance stabilization, the flap surgery was performed by implementation of Bio-Oss spongiose and Bio-gide membrane. RESULTS: 1. no inflammation 2. teeth mobility decreased 3. bone structure regeneration 4. minimal gingiva retraction CONCLUSION At advanced periodontitis followed by a significant bone loss, good results can take place if the initial therapy and surgical intervention were performed. Better clinical and radiological parameters were acquired, as well as the possibility of making new prosthodontic structures. The expected gingiva retraction was minimal.

\subsection{DENTAL IMPLANT FRACTURE CAUSED BY UNFAVORABLE} OCCLUSAL LOADING

Marija Nosić1, Tajana Novak2, Marija Ivić-Kardum3, Andrija Bošnjak1

1Department for oral medicine and periodontology, Study of Dental Medicine,

School of Medicine, University of Split

2 Private dental office, Zagreb

3Department of Periodontology, School of Dental Medicine, University of Zagreb

Implant placement today has become increasingly popular among dental clinicians because of benefits and the range of features over other interventions in dental medicine. Since it has led to an upsurge in dental medicine and more frequent use of the number of inserted implants increases daily and so does the frequency of complications. Fracture of dental implantsis one of the rare and late complications and is a sign of excessive occlusal overload. Here we present a case of 67 year old patient who complains of implant hypermobility of the implantoprostheticly substituted tooth in a region 45. Radiological analysis revealed that the reason for loose implant was a cervical fracture at the screw level. The implant was $3.3 \mathrm{~mm}$ wide 3I implant with metal ceramic crown suprastructure. Medical history revealed that the patient did not suffer from temporomandibular disorder or any other occlusal disorder. Oral rehabilitation was done six years ago when the implants were placed in a region 36 , 37 and 45. Implant fracture is a irreversible implant complication and in this case it was decided to explant the fractured implant, and to augment the defect and when it heals to implant a wider implant in the place.

12.2. ROOT COVERAGE IN THE LOWER ANTERIOR TOOTH SEGMENT - REPORT OF TWO SURGICAL TECHNIQUES

Jelena Prpić1, Davor Kuiš1, Ivana Šćiran1, Marija Ivić-Kardum2, Andrija Bošnjak1

IDepartment for Oral Medicine and Periodontology, Medical School, University of Rijeka

2Department of Periodontology, School of Dental Medicine, University of Zagreb

Gingival recession of the buccal tooth surface, especially involving anterior teeth, is a common finding in populations with high standards of oral hygiene. The following causative factors were proposed: traumatic toothbrushing, morphological defects associated with the gingiva and alveolar bone, and possibly functional defects. Surgical techniques developed for treatment of recessions may be divided into pedicle flaps and free soft tissue grafts. Regenerative materials may also be added to complement these procedures. Nowadays, coronally advanced flap in combination with connective tissue graft $(\mathrm{CAF}+\mathrm{CTG})$ is considered to be the gold standard for treatment of gingival recessions. Potential of the free gingival graft (FGG) for root coverage is significantly inferior. However, majority of case reports and investigations included only upper teeth. In the lower anterior area, success is frequently compromised by narrow attached gingiva, high insertion of frenulum, and shallow fornix. Therefore, a new technique - partly epithelialized free gingival graft (PE-FGG), has been recently introduced, with potential of predictably improving the esthetic outcome of root coverage in the lower anterior segment, while overcoming the detrimental effect of the above mentioned factors. Additional advantage of this technique includes retention of the original position of the mucogingival junction, which is not the case with "standard" FGG. Two cases of gingival recession in the lower anterior tooth segment are presented, together with two surgical techniques for root coverage: $\mathrm{CAF}+\mathrm{CTG}$ and PE-FGG. 


\subsection{TERAPIJA PARODONTNOG APSCESA DONJEG SREDIŠNJEG} INCIZIVA-PRIKAZ SLUČAJA

Josip Prpić1, Vlatko Pandurić2, Darije Plančak3

1Ordinacije dentalne medicine Josip Prpić, dr.med.dent. i Lidija Prpić, dr.med. dent.

ZZavod za endodonciju i restaurativnu stomatologiju, Stomatološki fakultet, Sveučilište u Zagrebu

ZZavod za mikrobiologiju, Medicinski fakultet, Sveučilište u Zagrebu

UVOD: Pacijentica se javlja u parodontološku ambulantu s akutnim bolovima i otokom u regiji 31 i 41 . U anamnezi navodi insuficijenciju mitralnog zaliska. Anamnezom, parodontološkim pregledom i analizom ortopantomograma postavljena je dijagnoza parodontnog apscesa na zubu 31. PRIKAZ SLUČAJA: Anamnezom je utvrđena insuficijencija mitralnog zaliska te je nakon pregleda propisana antibiotska profilaksa. U prvoj posjeti je napravljen cijelokupni pregled uz uklanjanje supragingivnih naslaga i inicijalnu terapiju područja 31,41 . Pacijentica je upućena na Zavod za endodonciju i restorativnu stomatologiju radi endodontskog liječenja zuba 31 i postavljanja interkanine lingvalne fiksacije. Pacijentica se javila na kontrolni pregled drugi i treći dan gdje je primjećeno znatno smanjenje otoka, dok pacijentica navodi subjektivno bolji osjećaj. U peridu od 2 tjedna završena je inicijalna terapija cijele usne šuplijne. Pacijentica je bila na kontrolnom pregledu nakon mjesec dana. Nakon 3 mjeseca ućinjena je kontrolna intraoralna rtg snimka gdje se vidi uspješno liječenje zuba 31 te oporavak potpornih struktura zuba. Pacijentica ne navodi nikakve smetnje. ZAKLJUČAK: Slučaj prikazuje kako se dobrom suradnjom između spec. parodontologije i spec. endodoncije i restorativne stomatologije mogu sanirati slučajevi čija problematika pripada u oba područja dentalne medicine.

\subsection{UTJECAJ RUBA KRUNICE NA ZDRAVLJE PARODONTA Igor Repušićl, Andrej Aurer2 \\ IDom zdravlja KZŽ; Ordinacija dentalne medicine, Pregrada \\ ZZavod za parodontologiju, Stomatološki fakultet, Sveučilište u Zagrebu}

Svrha ovog istraživanja bila je ispitati utjecaj odstojećih rubova krunica na zdravlje parodonta usporedbom parodontnih indeksa prirodnih zubi i zubi opskrbljenih krunicama. Istraživanje je obuhvatilo 85 pacijenata liječenih fiksnoprotetskim radovima. Anamnestički su registrirani čimbenici rizika upalnih parodontnih bolesti, te izmjereni parodontni indeksi (PI, PBI, PD, zahvaćenost furkacija) i rubna adaptacija krunica. Provedena je statisticka analiza prikupljenih podataka koristeći SPSS for Windows 16.0 Prosječna dob pacijenata je bila $50.44 \pm 12.6$ godina, a ukupno je izmjereno 2019 zuba i 303 krunice. Prosječni parodontni indeksi zubi bili su $\mathrm{PI}=0.402 \pm 0.468, \mathrm{PBI}=1.561 \pm 0.999, \mathrm{PD}=2.822 \pm 0.963$, a krunica $\mathrm{PI}=0.561 \pm 0.460, \mathrm{PBI}=2.415 \pm 1.177, \mathrm{PD}=2.991 \pm 1.067$. Prosječno je nađeno 3.56 krunica po pacijentu, a odstojale su $1.17 \pm 0.45 \mathrm{~mm}$. Nađena je statistički značajna korelacija PBI i odstojećih rubova krunica ( $\mathrm{p}=0.007)$, kao i značajna razlika između indeksa upale zubi i krunica $(\mathrm{p}=0.001)$. Statistički je dokazana značajna razlika vrijednosti PI i PBI indeksa između pojedinih stupnjeva odstojanja rubova krunica. Ovo istraživanje potvrdilo je da su upalna stanja gingive oko krunica izraženija nego oko zubi. Činjenica da je većina pregledanih rubova krunica odstojala u prosjeku preko $1 \mathrm{~mm}$, ukazuje na potrebu poboljšanja kvalitete fiksnih protetskih radova, što bi umanjilo vjerojatnost pojave ili progresije upalnih parodontnih bolesti.

\subsection{KIRURŠKA TERAPIJA VIŠESTRUKIH RECESIJA GINGIVE \\ Marija Roguljić1, Darko Božić2, Darije Plančak2, Ante Ćurić1 \\ 1Stomatološka poliklinika Split \\ ZZavod za parodontologiju, Stomatološki fakultet, Sveučilište u Zagrebu}

Pacijentica u dobi od 25 godina javlja se zbog generaliziranog povlačenja zubnog mesa u gornjoj čeljusti i preosjetljivosti izloženih korijenova zuba. Kliničkim pregledom utvrden je tanki biotip gingive. Pacijentica je nosila fiksni ortodontski aparat tri godine. Nakon detaljnih uputa u tehniku četkanja i pracenja 6 mjeseci odlučeno je kirurškim zahvatom koronalno pomaknuti gingivu te prekriti eksponirane korijenove. Korištena je tehnika koronalno pomaknutog režnja po Zucchelliju i DeSantisu u kombinaciji sa subepitelnim vezivnim transplantatom uzetim s nepca. Režanj je fiksiran u novi polažaj pojedinačnim šavovima koji su uklonjeni nakon dva tjedna.

\subsection{TREATMENT OF PERIODONTAL ABSCESS OF THE LOWER} CENTRAL INCISOR-A CASE REPORT

Josip Prpić1, Vlatko Pandurić2, Darije Plančak3

1Dental office Josip Prpić, dr.med.dent. i Lidija Prpić, dr.med.dent.

2Department of Endodontics and Restorative Dentistry, School of Dental

Medicine, University of Zagreb

3Department of Periodontology, School of Dental Medicine, University of Zagreb

INTRODUCTION: A patient visited the periodontal clinic with acute pain and swelling in the region of 31 and 41 . The patient noted insufficiency of the mitral valve. Medical history, periodontal examination and orthopantomogram analysis indicated a diagnosis periodontal abscess on a tooth 31. CASE: The patient reported mitral valve insufficiency and therefore after examination, antibiotic prophylaxis was prescribed. In the first visit a complete review and removal of debris and supragingival calculus were performed and also, a deep scaling and root planning of areas 31,41 . Afterwards the patient was sent to the Department of endodontics and restorative dentistry for endodontic treatment of tooth 31 and placing lingual intercanine fixation. The patient returned for the check-up the second and third day, where we observed a significant reduction of the swelling and the patient reported a subjective feeling better. In a period of 2 weeks, initial treatment of the entire oral cavity was completed. After a month the patient came for a follow-up examination. After 3 months a control intraoral radiography of intercanine region showed a successful treatment of tooth 31 and the recovery of the support structure of the tooth. The patient reports no complication. CONCLUSION: The case shows how the good cooperation between the spec. of periodontics and the spec. of endodontics and restorative dentistry can solve problems of cases that belong in both fields of dental medicine.

\subsection{INFLUENCE OF CROWN MARGIN ON PERIODONTAL HEALTH Igor Repušić1, Andrej Aurer2 \\ IDental practice, Pregrada \\ 2Department of Periodontology, School of Dental Medicine, University of Zagreb}

Tha aim of this study was to investigate the influence of overhanging crown margins on periodontal health by comparing periodontal indices of natural and crowned teeth. Eighty five patients were included, treated with fixed reastaurations. Risk factors for periodontal diseases, periodontal indices (PI, PBI, PD, furcation involvement) and overhangings of crown margins were recorded. Statistical analysis was performed using SPSS for Windows 16.0 software. Mean age was $50.44 \pm 12.6$ years, and in total 2019 teeth and 303 crowns were recorded. Mean values for periodontal indices for teeth were $P I=0.402 \pm 0.468, P B I=1.561 \pm 0.999, P D=2.822 \pm 0.963$, and $P I=0.561 \pm 0.460$, $\mathrm{PBI}=2.415 \pm 1.177, \mathrm{PD}=2.991 \pm 1.067$ for crowns. On average, 3.56 crowns per patient were observed, and the mean overhang for crowns was $1.17 \pm 0.45 \mathrm{~mm}$. Statistically significant difference was found for PBI and overhanging margins ( $p=0.007)$, as well as difference between inflammatory indices of natural teeth and crowns $(\mathrm{p}=0.001)$. Significant difference was also observed between individual quantitative degrees of crown overhangs. This investigation confirmed that periodontal inflammatory changes are more frequent in comparison to natural teeth. The fact that most of the crowns had overhangs of more than $1 \mathrm{~mm}$ clearly shows the need for a better quality and fit of crowns, and thus eliminate or reduce the probablity of initiation or progression of inflammatory periodontal diseases.

\subsection{SURGICAL THERAPY OF MULTIPLE GINGIVAL RECESSION DEFECTS}

Marija Roguljić1, Darko Božić2, Darije Plančak2, Ante Ćurić1

1Dental Polyclinic Split

2Department of Periodontology, School of Dental Medicine, University of Zagreb

A 25-year old female patient presented complaining of the generalized gingival recession and root sensitivity in the upper jaw. Patient has been in the orthodontic treatment for 3 years. She was given a meticulous instructions about dental brushing technique. Six months later it was decided to cover denuded roots surgically. Coronally advanced flap procedure in combination with connective tissue graft from palate was performed. The flap was sutured by interrupted sutures. Two weeks later the sutures were removed. 


\subsection{ENDODONTSKA I PARODONTNA TERAPIJA U LIJEČENJU ENDO- PARO LEZIJA - PRIKAZ SLUČAJEVA \\ Ivana Šćiran1, Alen Braut2, Davor Kuiš1, Jelena Prpić1,Andrija Bošnjak1 \\ IKatedra za oralnu medicinu i parodontologiju, Medicinski fakultet u Rijeci, Sveučilište u Rijeci \\ 2Katedra za endodonciju i restaurativnu dentalnu medicinu, Medicinski fakultet u Rijeci, Sveučilište u Rijeci}

Zubna pulpa i parodont su u bliskom anatomskom kontaktu te međusobno komuniciraju putem dentinskih tubulusa, lateralnih i akcesornih kanalića te preko apeksnog foramena. Apikalni foramen je glavni i najizravniji put komunikacije pulpe i parodonta, stoga se infekcije iz dubokih parodontnih džepova koji dosežu apeks mogu prenijeti na pulpu i obrnuto. Isto tako, pulpa neće biti zahvaćena upalom sve dok recesija gingive ne otvori puteve komunikacije preko dentinskih tubulusa i akcesornih i lateralnih kanalića prema pulpi. Kada jedno od ta dva tkiva biva inficirano, mikroorganizmi cirkuliraju između tkiva, te bolest jednog tkiva može uzrokovati patozu drugog ili pak pogoršati trenutačno stanje. Endo-paro lezije se mogu klasificirati u primarno endodontske, primarno parodontne i „prave" kombinirane lezije, te ovisno o tome se provodi endodontska, parodontna ili kombinirana terapija. Dobar i pravilan odabir tehnike i procedura pri liječenju endodontskih infekcija su ključ za uspjeh terapije. Dobro čišćenje, oblikovanje i obturiranje sistema endodontskih kanala je imperativ. Periapeksno cijeljenje može biti predviđeno uspješno provedenom endodontskom terapijom, dok cijeljenje parodontnih tkiva nije u takvoj točnosti predvidljivo, te ovisi o ozbiljnosti i raširenosti kombiniranih lezija. Poster prezentacija će prikazati nekoliko kliničkih slučajeva.

\subsection{ENDODONTIC AND PERIODONTAL THERAPY IN TREATMENT OF ENDO-PERIO LESIONS - CASE REPORTS \\ Ivana Šćiran1, Alen Braut2, Davor Kuiš1, Jelena Prpić1, Andrija Bošnjak1 IDepartment for Oral Medicine and Periodontology, Medical School, University of Rijeka \\ 2Department of Restorative Dentistry and Endodontic,Medical School, University of Rijeka}

The pulp and periodontium are in a very close anatomic relationship. They communicate through dentinal tubules, lateral and accessory canals and apical foramen. Apical foramen is the main and most direct way of communication between pulp and periodontium, so infections from deep periodontal pockets reaching the root apex may affect pulp and vice versa. However, the pulp won't be affected by inflammation until gingival recession opens the communication pathways through dentinal tubules, accessory and lateral canals towards the pulp. When one of these two tissues is infected, microorganisms circulate between them, and infection of one tissue may cause pathology of another or exacerbate the current disease. Endo-perio lesions are classified as primary endodontic, primary periodontal and "true" combined lesions. Accordingly, we may decide to perform root canal, periodontal or combined therapy. Adequate choice of treatment technique is the key to successful healing. Good quality and correct shaping and filling of root canal system are the imperatives. Periapical healing can be achieved with successful root canal therapy, but healing of periodontium is not as predictable- it depends of severity and spread of combined lesions. Poster presentation will show several clinical cases. 